\title{
THE COMPETITION BETWEEN COCA COLA \& PEPSI BRANDS IN TURKISH MARKET: THE BRAND LOYALTY
}

Blesa Ibrahim Mohammed ${ }^{1}$

\begin{abstract}
The purpose of this paper is aims to investigate no aperant cola war existing between cocacola and pepsi campared with other majer markets in the world.and explore the factors that help turkish people to choose cola as a soft drink. The study show that there is potential in the Turkish market and the consumers are not fully loyal to Coca Cola, since a unit change in Coca Cola's Brand/Advertising Communication can bring about significant decrease in their chances for being chosen by the consumer which shows that there is still room for improvement from Coca Cola on that part. Indicating that in the Turkish consumers' mind Coca Cola is still not well established and Pepsi has a lot to fight for, provided Pepsi is willing to start the Cola war in Turkey. The results also show that proper distribution and an consumer engaging Marketing strategy some of which are also advised in the paper Pepsi can bring the fight to Turkish Territory as well.
\end{abstract}

Keywords: Brand loyalty,consumer prefernce factors,cola war.

\section{INTRODUCTION}

Since its inception in the late 1800s, Coca-Cola has experienced astronomic growth, progressing from nine glasses per day to nearly 1.7 billion Coke servings per day (statisticbrain.com). Today, Coca-Cola offers more than 3500 controls the highest market share $(41,9 \%)$ in the soft drink market (InvestmentU.com,2011). In addition to its leading global market share, Coca-Cola also retains the title of having the most popular individual beverage in the world in Coca-Cola Classic, with a 26\% market share (statisticbrain.com). Additionally, in 2012 it placed four beverages in the top 10 for individual product sales: Coke Classic (\#1), Diet Coke (2), Sprite (6), and Fanta (9) (energyfiend.com). Through Research \& Development (R\&D) and acquisitions, Coca-Cola has also expanded its product line to include non-carbonated beverage products, including:Dasani, Fruitopia, Hi-C, Minute Maid, and Mr. Pibb. In 2010, Coca-Cola spent approximately $\$ 2.9$ billion on marketing and advertising (businessinsider.com).

\footnotetext{
${ }^{1}$ Accounting Department, Faculty of Administration and Financial Sciences, Cihan University, Sulaimani, Iraq
} 


\section{The Challenger of pepsi}

With the exception of brief bankruptcy periods in 1923 and 1932, Pepsi-Cola assumed its place at the heels of Coca-Cola through its creation of an extensive franchise bottling network and distribution outlets (Yoffie, 2004). Over the years, the Pepsi-Cola company has expanded its product offerings, through R\&D and acquisitions, to include: Diet Pepsi, Mountain Dew, Mug Root Beer, Slice, Sierr Mist, Lipton, Aquafina, and Starbucks Frappuccino, among others.

Pepsi- Cola's acquisition of Gatorade from the Quaker Oats company in December 2000 further proved its commitment to broadening its product base as well as expanding its sponsorship connection to the sport industry, in which Gatorade was already a major player.As of 2011, Pepsi controlled 29,9\% (InvestmentU.com) of the market in the soft drink industry with annual sales of 3.2 billion cases ("Top 10," 2004). Today, the company's flagship brand, Pepsi-Cola, ranks second only to Coca-Cola Classic, with a Turkish market share of 6,9\% (statista.com, 2010). Similar to the Coca-Cola company, it also has four products in the top 10 on an individual product sales basis: Pepsi (\#3), Mountain Dew (4), Diet Pepsi (7), and Diet Mountain Dew (8) ("Top 10," 2012). In 2012, Pepsi increased its marketing and advertising budget by 500 to 600 million dollars (adage.com).The following graphs shows the leading Brands in terms of value within the Soft drink category very clearly marks Pepsi's challenger position in the world market.

\section{* Source APCO Statista2012}

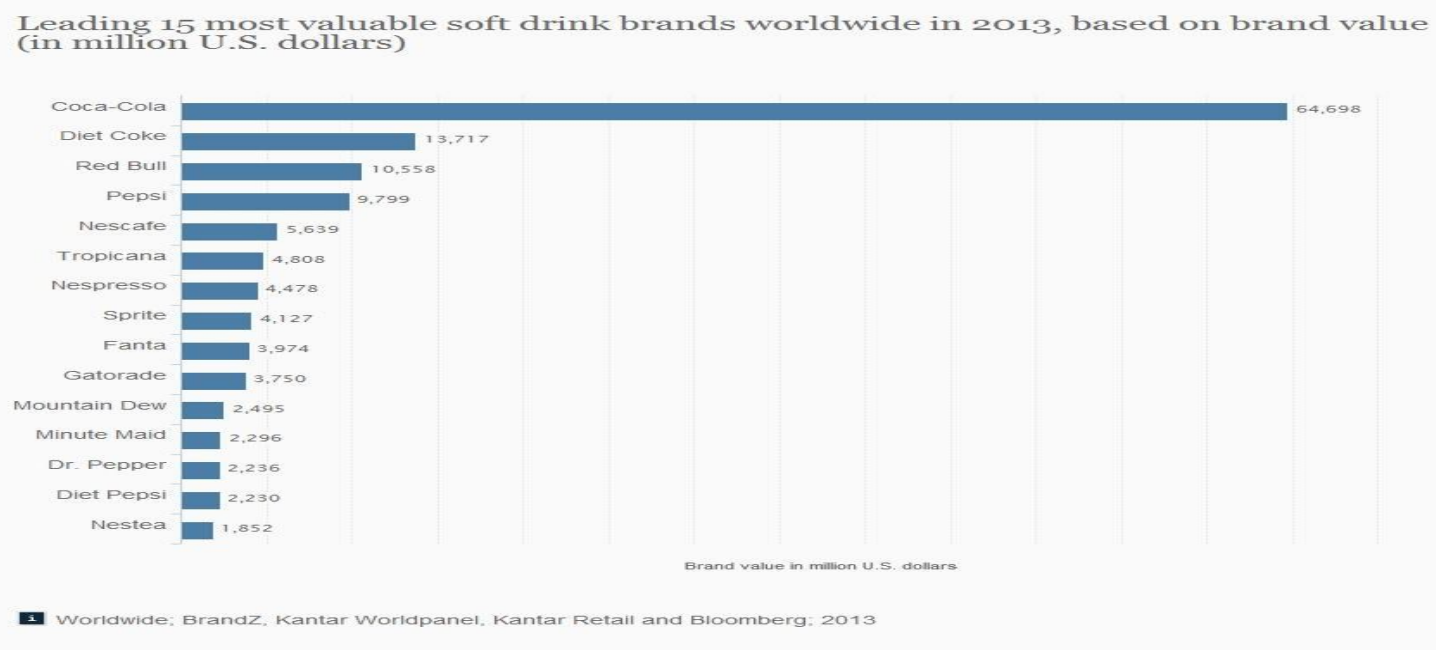

statista

\section{Investigation cola in Turkish Market}

Turkey, a country with a population of 90 million, is a good market for any soft drink brand. But what is worth noticing is that there is almost no amount of marketing activity that is being observed by Pepsi the Challenger in the cola war game. So the question arises why the certain silence on Turkey's turf? Has the Challenger given up on the Turkish market?

On the international arena there are only 2 brands separating Coke and Pepsi on the list of favourite Brands 
Most loved companies worldwide in 2013

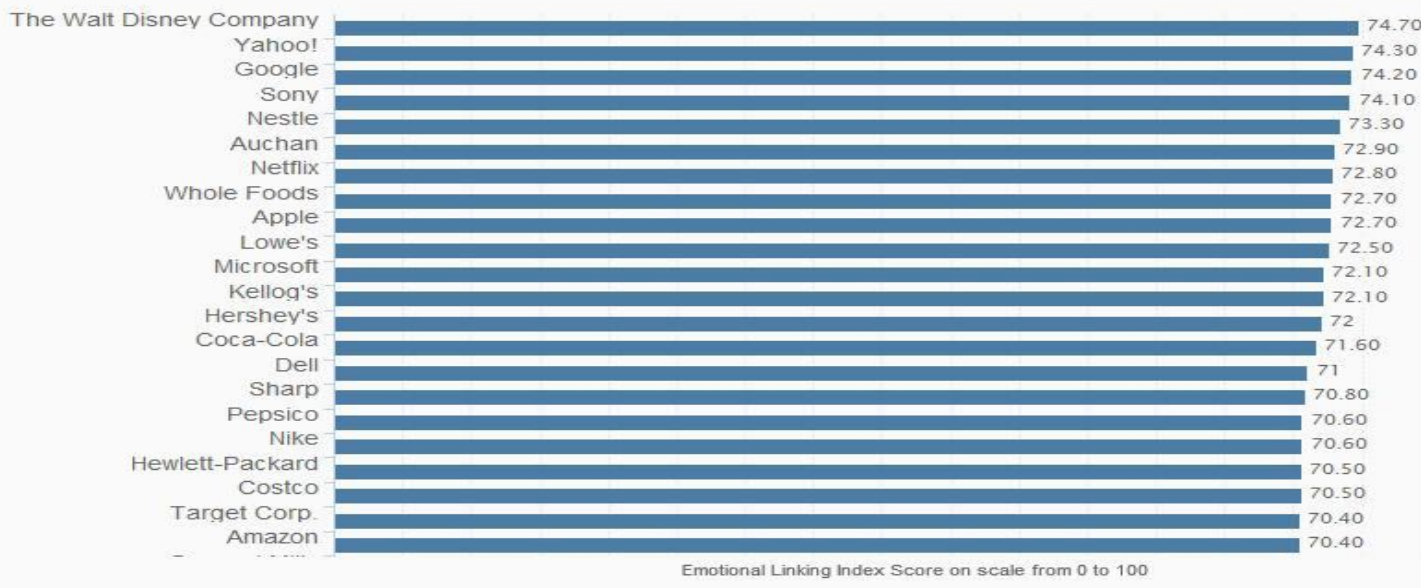

i. Worldwide; $n=70,000$ consumers from 15 countries

\section{statista}

\section{* Source APCO Statista 2012}

Having said that we do see Pepsi's presence in some Turkish stores and supermarkets, so its not only a matter of Pepsi not wanting to win the hearts of Turks but they are not committing to it seriously. The analysis can guide us to understand what really is the differential factor that is having an effect on the preferences of the Turks when it comes to selecting cola especially amongst the youth, which has been a focal point in all major communications by Pepsi. Even though it is evident that overall in 2013 Pepsi has been spending more in advertising than Coke all over the world the situation is pretty different here in Turkey. 


\section{Advertising spending of selected beverage brands in the in the United States in 2012 (in million U.S. dollars)}

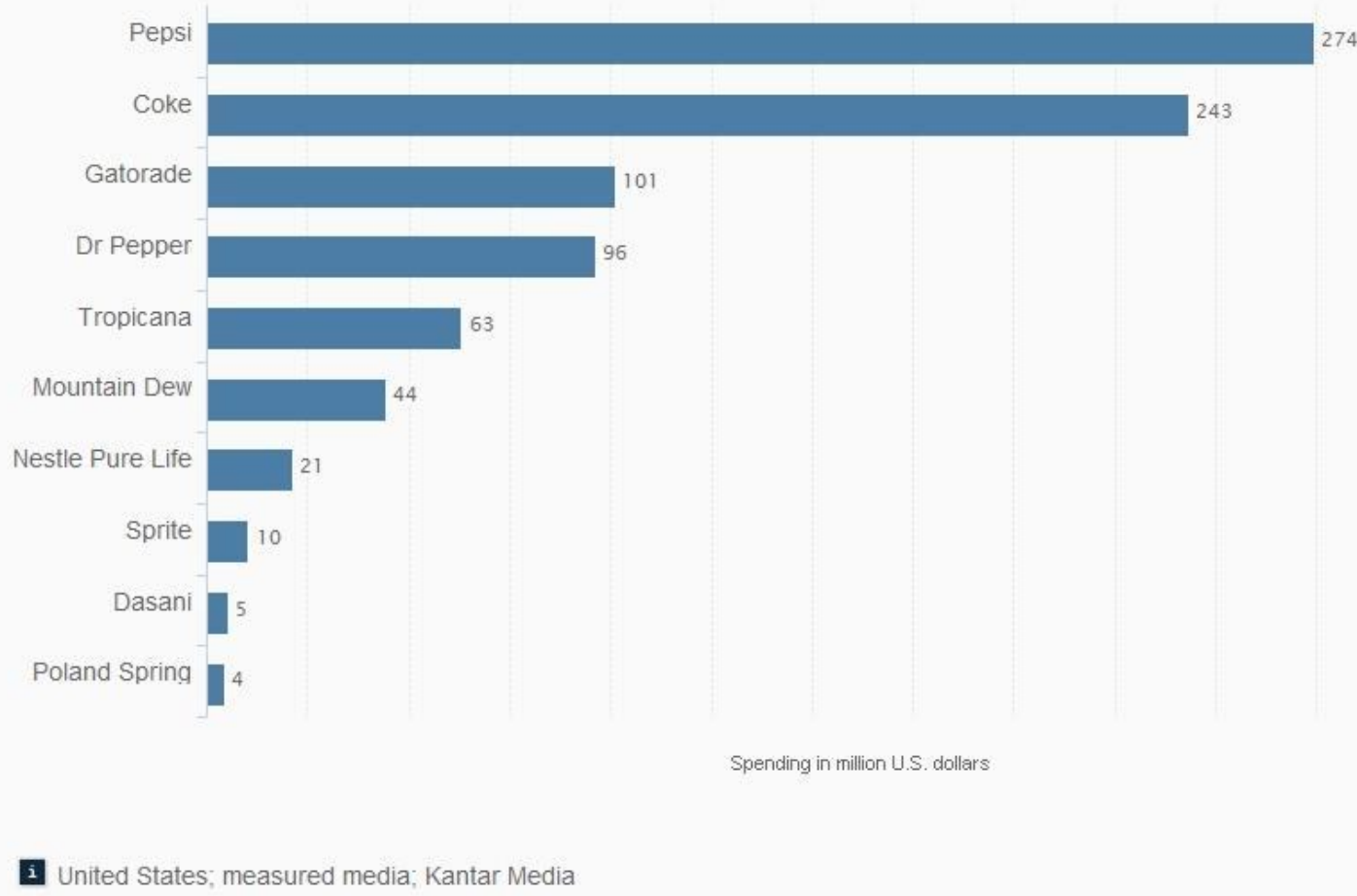

\section{statistar}

\section{* Source APCO Statista 2012}

So why is that the major challenger in the cola industry so quiet in Turkey why is the Turkish population (especially youth) expected to behave differently than they are anywhere else in the world?

We want to study such behavioural aspects and what actually influences the Turkish youth to select or deselect either cola brand, because many if not all behavioural scientists, including Freud, believe that there exists an explanation for all behaviors even if the explanation exists in the unconscious. Thus, according to Frank M. Bassusing (1974) 'works such as those by Howard and Sheth, and Engel, Kollat, and Blackwell, however valuable they may have been in providing structure and framework for empirical research, may have misdirected research by implicitly overemphasizing deterministic models of behavior'.

There are underlying variables to choice and they are complex to the extent that even consumers 
themselves sometimes cannot clearly define them or describe why they would prefer one over the other. The research will try to figure out what are the reasons for changes in preferences. A hypothesis is that the preferences for Coke and Pepsi differ on the basis of gender. But as we conduct our research more insights will be discovered.

\section{RESEARCH METHODOLOGY}

The research is primarily based on a survey 175 university students took part in the survey explaining replying to 10 questions regarding their preferences for Coke or Pepsi. These replies were then analyzed to figure out what influences the choice between colas. The research may not be conclusive to resolve the choice matter as explained earlier that its far more complex, but it can surface some underlying reasons to behaviour and attitudes towards these brands in the Turkish market.

Nominal Regression was used to analyze the compiled data. With reference to Coke first and then Pepsi. To further understand what measure play important part for which brand. The participants were asked series of questions indicating their preference level and choices along with consumption pattern.

\section{QUESTIONNAIRE}

To see the exact questionnaire, please refer to Appendix. 1

\section{LITERATURE REVIEW}

According to the Network Models for Estimating Brand-Specific Effects in Multi-Attribute Marketing Models by V. Srinivasan (1979), two products or candidate for a political party may have similar attributes but have quite different market shares. In the example of our brands in question, Coke and Pepsi, Srivnivan stresses that both have similar attributes - "sweetness", "carbonation", "calories", and "price". Further statistical equations were derived to reach the conclusion that attributes are not the only factor when it comes to consumer preferences.

Frank .M Bassusing (1974), using "Herniter's Entropy Theory", suggested that brand choice behaviour is substantially stochastic. A bundle of other research is available over the subject of choice and preferences. For example, the C. W. J. Granger and A. Billson 'Consumers' attitude towards package size and price" (1972) explains peoples' choices for switching to larger packs when price per unit information was explicitly provided. "A Paired Comparison Nested Logit Model of Individual Preference Structures" by William L. Moore and Donald R. Lehmann (1989) tried to solve the preferential dilemma by Logit model and concluded that studying the market at a more disaggregate level is better than single preference choice structure.

Similarly, in 2008 scientists Michael Koenigs and Daniel Tranel from the department of Neurology, in the University of Iowa College of Medicine and Neuroscience, conducted a blind test between Coke and Pepsi. The blind test showed that more people prefer Pepsi over Coke, but in a semi blind test with brand information provided their preferences skewed towards Coke. This suggests that taste is not the result of Coke's bigger market share, ruling out any contribution that taste might have in the equation. When the test was performed on patients with brain damage in the regions connected to emotions, they did not display preference towards Coke in any of the cases.

This shows there is an emotional connection that the non-damaged subjects had with Coke, which was not present in case of Pepsi. A similar conclusion was reached in a study by Samuel M. McClure, Jian Li, Damon Tomlin, Kim S. Cypert, Latane’ M. Montague, and P. Read Montague from the Department of Neuroscience Menninger Department of Psychiatry and Behavioral Sciences Baylor College of Medicine Neuron, Vol. 44, 379-387, October 14, 2004, Copyright 2004 by Cell Press. 


\section{Number Crunching}

The Nominal method has been used to understand what factors are significant when it comes to affecting the choices of consumers in selecting their brand of cola. Since respondents are from the Turkish market we can also say that the factors are perceived important by the Turkish consumers while selecting their brand of cola.

The decisive parameters for the research:

$\begin{array}{lcccc}\begin{array}{l}\text { Parameters references for making choices } \\ \text { Variables }\end{array} & \text { Sig } & \text { B } & \text { B(Exp) } & \text { Std.Er } \\ \text { Image/Brand Value } & .027 & -3.169 & .042 & 1.430 \\ \text { Taste } & .007 & -4.473 & .011 & 1.644 \\ \text { Price } & .405 & 650 & 1.915 & .780 \\ \text { Availability } & .003 & 2388 & 10.89 & 1.516 \\ \text { Advertising } & .019 & -2023 & .132 & 1.296\end{array}$

\section{a: Reference to Coca Cola}

The Model:

$\mathrm{P}($ Coke $) /$ Pepsi $)=\operatorname{Image}(\mathbf{0 . 4 2})+\operatorname{Taste}(0.11)+\operatorname{Price}(1.91)+$ Availability $(10.89)+$ Advertising $(1.296$

Ho :- Image0 = 0 , Taste0 = 0 , Price0 = 0, Advertising0 =0, Availability0=0 H1 :-

Image $1 \neq 0$, Taste $2 \neq 0$, Price $3=0$, Advertising $4 \neq 0$, Availability $5 \neq 0$

\section{Note: Reject Null Hypothesis with exception of Price. For Price Null Hypothesis accepted}

\section{Analysis}

Observing the equation above we can determine that the major contributors to Coca-Cola's success are mainly its investment in the brands and advertising, alongside presences at all levels of distribution, something that Pepsi has been neglecting to date in the Turkish market.

\section{Choice Factors}

'Taste'

As expected from the studies of 2008 by scientists Michael Koenigs and Daniel Tranel from University of Iowa, most people can not even differentiate between Pepsi and Coca Cola as per the equation also taste is significant but here this implication of Taste is more relative to the perception about the brands. which is indicated by the equation to be very significant thus the label on the bottle is creating that 
satisfaction in the minds' of the consumers we will discuss Image and Brand Value in much detail in the subsequent paragraphs of the Analysis, lets now first concentrate on the perceptual value of ' $\boldsymbol{T A S T E}$ ', and how it is showing a very similar picture as to what the U.S.A's consumers depicted nearly 3 decades ago. Taste even though none identifiable by the consumers' brain here is indicated by the (-) Negative impact showing: when a unit change in taste occurs it drops the likelihood of selection of coke over pepsi by $89 \%$. Now lets take a journey down memory lane referring to the ' $\boldsymbol{C O K E} \boldsymbol{N E W} \underline{\boldsymbol{L A U N C H}}$ 'in 1985 when The Coca-Cola Company took arguably the biggest risk in consumer goods history, announcing that it was changing the formula for the world's most popular soft drink, and spawning consumer angst the likes of which no business has ever seen. ( http://www.coca-colacompany.com/stories/coke-lore-new-coke) the story is not much different when it comes to the young turkish market. A expected drop in probability of Coca-Cola's selection over Pepsi by $73 \%$ with a significance level of .007 is a strong indicator.

\section{Choice Factors}

\section{'Image,Brand Value \& Advertising'}

The research questionnaire evaluated the preferability of the two cola's advertising and Communication efforts both in terms of preferences of one over the other by an individual consumer by ranking over a scale of 1 to 5 - with 5 being higher value. For simplicity of the Analysis Image, Brand Value and the Advertising and Communication response from the Model are discussed collectively.

This is strongly indicted with a significance value of (.405) 'PRICE' not being a significant indicator in the model so we accept the NULL hypothesis only in this case or factor. So the whole conundrum is relying on the perception between the two brands which is the same situation as it is in anywere else in the world between the two Cola giants. this in turn another reason for Pepsi to get active in the Turkish market, because any measure of unit change in Cokes brand image or in the level of their advertising can potentially decreases the probability of selection of Coke by a staggering $68 \% \& 87 \%$ on the bases of Brand Image and Communications \& Advertising respectively. Indicating the value of investing in Brand related activities that can improve of either selection or selection of Coke. It also indicates the fragile nature of Coca-Cola's Brand Equity in Turkey which can be capitalized by Pepsi. The significance level of Branding and Advertising efforts is also very high. Looking from Pepsi's perspective this is an opportunity to create brand differentiation in the minds of the turkish consumers via aggressive advertising and communications.

\section{Choice Factors}

\section{'Availability'}

Proper distribtion is one of the most important pillars of a successful brand and its again shows that Coke has done a better job at distribution than Pepsi. The distribution efforts can also be attributed to the retail stores willingness and eagerness to keep Pepsi stocks but that is not the concern of the research for now we are observing that how availability affects the choice of Cola. As indicated by our model distribution is significant as shown by (.003) as availability of Coca-Cola increase the probability of its selection over Pepsi by almost $11 \%$. This can be read as an advantage of Coke over Pepsi but it also shows that since the percentage is not a very high one Pepsi still can give Coca Cola a fight by properly and actively engaging in distribution in the Turkish market.

\section{Choice Factors}

\section{'Other Alternatives in the Soft Drink Industry'}

Understanding from Frank M. Bass' Brand Switching Model it can be derived from the section of "The theory of long-run probability of switching" that 'brand choice behavior is substantially stochastic'. As marketers we may not agree with the statement and findings completely but it does provide a basis for 
Pepsi to try and compete in Turkey, as it has done in a lot of other places in the world. It also depicts that markets for more healthier alternatives can grow as well. In a subsequent research we would analyze how these new alternatives are giving the soda drinks a run for their money.

\section{Other Parameters}

Certain parameters such as Gender, Income levels, Marital status, and Consumption Patterns were also analyzed, but it was found that they did not had any significant impact over consumer choice when it comes to selection of Coca-Cola or Pepsi. So the Null hypothesis is accepted for all above mentioned parameters as well but are not included in the final equation for reasons already stated.

However, these can not be ruled out while discussing the lost of popularity and the rise of alternative drinks and juices. A subsequent study to this Paper.

\section{CONCLUSION}

The statistics are certainly in favour of Pepsi to start the war, and the Turkish consumers are ready for a change. But this change requires Pepsi to attain to the challenger position in Turkey as well. Pepsi has venues same as it has in any other country. It has to work on the Brand Perception and invest in Advertising and heavy distribution in order to win the hearts and minds of Turkish population. Engaging in Sports sponsorships, or sponsoring youth programing over turkish television can pave way for Pepsi and can be helpful along with heavy distribution in major cities which is not only restricted to IMTs or LMTs((International and Local Modren Trades) but distribution to deeper traditional shops system especially in remote and smaller cities where presence of Pepsi is next to none. Even though Pepsi do posses a negotiating muscle through its snack brands at the retail level exercising that can be fruitful for Pepsi soda drink as well. Another important factor when discussing and encouraging Pepsi on promoting its very essential to keep in mind that the demographic and psychographic of the Turkish population are those rooted in family structure and religion. The universal Positioning by 'Pepsi' which is based around individualism may require localization. Another reason that Coca Cola is performing well can be that its a natural blend in terms of its Global Positioning to the Turkish market as oppose to Pepsi's positioning of Individualism Coca Cola builds its positioning around family and sharing. A detailed proposal paper can also be produced highlighting the effects of different positioning route that are available to Pepsi under its global positioning adapting to the Turkish population.

Turkey also has some national brands such as Le'Cola and Cola Turka, 'Cola Turka' is backed by a famous business group ' $\ddot{\boldsymbol{L}} \boldsymbol{K} \boldsymbol{E} \boldsymbol{R}$ ' emphasizing on 'Turkish Authenticity' 'although Ülker is one of the major representatives of "green capital”-i.e., Islamic capital—in Turkey, unlike other Islamic cola brands, it did not launch Cola Turka as a political statement against the exploitation of Muslims.' (Muslim Societies in the Age of Mass Consumption: Edited by Johanna Pink:Cambridge Scholars Publishing 12 Back Chapman Street, Newcastle upon Tyne, NE6 2XX, UK) even though Cola Turka still have not been able to win the turkish market since its launch almost a decade ago, Cola turka has been facing tremendous problems on the shelves due to its quality. But when it was launched in 2033 it did created a relatively good impact, which shows that if there is room for fight in the Coca Cola domination. If anything this is a good Omen for Pepsi.

The big question is will Pepsi grab this opportunity? Or are they looking to open some other fronts in the Turkish and especially in the global market? 


\section{REFERENCES}

[1]. Advertising Age. (n.d.). Advertising Age Latest News RSS. Retrieved December 22, 2013, from http://adage.com

[2]. Bassusing, F. M. (1974). The Theory of Stochastic Preference and Brand Switching. Journal of Marketing Research, XI, 1-20.

[3]. Coca-Cola Global: Soft Drinks \& Beverage Products. (n.d.). Coca-Cola Global. Retrieved December 19, 2013, from http://www.coca-cola.com/index.jsp

[4]. Energy Drinks. (n.d.). Caffeine Informer. Retrieved December 22, 2013, from http://www.energyfiend.com/category/energy-drink-brands/page/2

[5]. Granger, C. W., \& Billson, A. (1972). Consumers' attitude towards package size and price. Journal of Marketing Research, IX, 239-48.

[6]. Moore, W. L., \& Lehmann, D. R. (1989). A Paired Comparison Nested Logit Model of Individual Preference Structures. Journal of Marketing Research, 26(4), 420-428.

[7]. Srinivasan, V. (1979). Network Models For Estimating Brand-Specific Effects In Multi-Attribute Marketing Models. Management Science, 25(1), 11-21.

[8]. Statista. (n.d.). Statista. Retrieved December 19, 2013, from http://www.statista.com/

[9]. Statistic Brain | Numbers | Percentages | Financials | Rankings | Statistic Brain. (n.d.). Statistic Brain RSS. Retrieved December 20, 2013, from http://statisticbrain.com/

[10]. The Best Investment Advice for 2014. (n.d.). Investment U RSS. Retrieved December 22, 2013, from http://www.investmentu.com/

[11]. The Whole Story About China Being The Biggest Foreign Owner Of US Debt Is On The Verge Of Going Away. (n.d.). Business Insider. Retrieved December 19, 2013, from http://www.businessinsider.com/

[12]. Official Company Website: http://www.coca-colacompany.com/stories/coke-lore-new-coke Muslim Societies in the Age of Mass Consumption: Edited by Johanna Pink:Cambridge Scholars Publishing 12 Back Chapman Street, Newcastle upon Tyne,

NE6 2XX, UK 


\section{Appendix- A: Questionnaire}

1. What is your gender?

Female

Male

2. What is your age?

Below 18

$18-21$

$22-25$

26-30

Above 30

3. What is your relationship status?

Single

In a relationship/Engaged

Married

Divorced/Seperated

Widowed

4. What in your monthly income?

Below 1000TL

1000TL - 2000TL

$2000 \mathrm{TL}-3000 \mathrm{TL}$

Above 3000TL

5. What influences your choice of cola?

Taste

Availability

Customer Loyalty

Brand Image

Price

Advertisements

I don't drink cola

6. On what occasion do you usually drink cola?

With a meal

Without food

Both cases

I don't drink cola

7. Rate your preference for Coca-Cola and Pepsi:

$$
\text { 1(low) } \quad 2 \quad 3 \quad 4 \quad 5 \text { (high) }
$$

Coca Cola

Pepsi

Other sodas

8. Rate the advertisements of Coca-Cola and Pepsi:

$$
\begin{array}{lllll}
\text { 1(low) } & 2 & 3 & 4 & 5 \text { (high) }
\end{array}
$$

Coca-Cola 
Pepsi

9. Would you switch brands if your preferred cola is not availabl

No, I stick to my preferred brand.

Sometimes I would switch brands.

I would drink whatever is available.

I don't drink cola.

10. How often do you drink cola?

Several times a day

Once a day

A few times a week

Once a week

Very rarely

Never 